\title{
Environment, Arbovirus Transmission and Control of Epidemics ${ }^{1}$
}

\section{Ambiente, Transmissão de Arbovirus e Controle de Epidemias}

\author{
Roger Cordellier ${ }^{2}$ \\ Nicolas Degallier ${ }^{3}$
}

CORDELLIER, R. \& DEGALLIER, N. Environment, Arbovirus Transmission and Control of Epidemics. Cad. Saíde Públ., Rio de Janeiro, 8 (3): 249-253, jul/set, 1992.

In order to illustrate the relationships between the biotopes (or phytogeographical zones). arbovirus vectors and vertebrate hosts (including man), and epidemiology, current knowledge on the transmission of Yellow Fever virus in West Africa is reported. A dynamic scheme has been devised to integrate the observed geographical distribution of cases and the timing of their occurrence. Two principal areas, endemicity and epidemicity, were defined according to the presence or absence of sylvatic monkey-mosquito transmission. The intensity and potential of contacts between humans and vectors depends on the degree of man-made changes in the environment, often increasing the extension of ecotone areas where the mosquitoes are easily biting at the ground level. Prevention and/or control of arbovinus diseases require detailed ecoepidemiological studies to determine: (1) the effective role of each potential vector in each phytogeographical region; (2) the risk factors for the people living in or near areas with a sylvatic transmission cycle; (3) the priorities - vaccination and/or control - for preventing the expansion of natural foci.

Keywords: Yellow Fever; Vectors; Ventebrate Hosts; Epidemiology; Control

From an arbovirologist's point of view, the environment is not only the aquatic humanassociated environment - as is the case for malaria or shistosomiasis - but that, where are living the diverse hosts of the studied infectious agent: the arboviruses.

It may be useful to remind that these viruses typically are transmitted biologically by arthropods between sylvatic vertebrates and, occasionally to man (Hervé et al., 1986). Once infected, the arthropod host is able to transmit the arbovirus during all its life and it is thus considered as a vector-reservoir.

\footnotetext{
'The present work was supported by ORSTOM (Institut Français de Recherche Scientifique pour le Développemem en Coopération), Pasteur Institute (Ivory Coast), the World Health Organization (Geneve), and the National Health Foundation/Ministry of Health (Brazil).

: ORSTOM, OI BP 1434, Bouaké, lvory Coast.

${ }^{3}$ ORSTOM/Instituto Evandro Chagas. C.P. 1128, Belém.

PA, 66090-000, Brasil.
}

On the other hand, the vertebrate host generally harbours the virus in its blood during only a few days, before being refractory to another infection.

In order to illustrate the absolute necessity to know the relative importance and relationships of each component of arbovirus cycles for controlling and eventually preventing epidemics, we will present the best epidemiological scheme which has been fitted to the dynamics of Yellow fever (YF) in West Africa (Germain et al., 1982; Germain, 1986; Cordellier, 1991). The role of human-caused changes of the environment, will be emphasized.

\section{ECO-EPIDEMIOLOGICAL TRANSMISSION SCHENE FOR YELLOW FEVER IN WEST AFRICA}

In West Africa, YF natural history have been studied during more or less 20 years, by 
the research staff of ORSTOM and Pasteur Institute, with help of WHO.

It has resulted from these studies a spatiotemporal dynamical scheme which is based essentially upon the nature of the biotopes, changed or not by man. From South northward, the vegetation of West Africa is of the following types: ombrophilic rainforest, semi-decidual forest, savannah-forest musaic, drier savannah and desert. Two ecoe:pidemiological areas have been superimposed to this succession: (1) the endemicity area and (2) the epidemicity area (Figure 1).

\section{The Endemicity Area}

The endemicity area is the region where the virus is circulating enzoo- and epizootically. Man may be contaminated according to various modalities.

\section{The Permanent Natural Focus}

The permanent natural focus of YF virus is constituted by the rainforest zone and some outside areas where the maintenance of the virus may be realized by vertical (= transovarial) transmission in mosquitoes.

In the ombrophilic rainforest, transmission is all-year long and restricted to a canopy monkey-mosquito cycle, without human contamination (the main vector is Aedes africanus).

\section{The Semi-Permanent Natural Focus}

In the semi-decidual forested zone, the sylvatic transmission can be interrupted during the short dry season. The mosquito vectors are mainly the same as in the preceding zone but lower canopy and intermediate strata of vegetation support more contacts between them and man. Thus, endemic emergent (sporadic of other authors) cases are encountered.

\section{The Seasonal Natural Focus}

In this zone, the complexity of the environment seems to be the greatest, with the mixing of forest-savannah mosaic, forest "islands", gallery forest and arborescent savannah.

Monkey populations are more concentrated and the potential vector spectrum wider, as much in forested biotopes (with A. africanus, A. opok, $A$. neoafricantus) as in the more open ones (with $A$. furcifer, $A$. luteocephalus, $A$. taylori, $A$. vittatus). Seasonal epizootics occur and the human contaminations are more frequent, due to the greater number of ecotones and human settlements.

\section{The Endemic Emergence Zone}

This zone is covered by semi-humid savannahs, where the populations of mosquito vectors are denser and the monkeys are terrestrial species.

Accordingly, all mosquito species are able to bite at ground level and even, like $A$. furcifer, inside dwellings in villages.

The sylvatic transmission is epizootic, with numerous emergent human cases.

Human exploitation of the environment (called anthropisation) to the detriment of forest is thus increasing the risk for his contamination.

\section{THE EPIDEMICITY AREA}

The epidemicity area is exempt from sylvatic circulation of the virus. It extends beyond the emergence front which limits northwardly the endemicity area. Included in this area are also all towns located in the endemicity area and where domestic or peridomestic A. aegypti is present. In this area, human behavior is very important because he is actually importing the virus and effectively breeding the urban YF mosquito.

\section{PREVENTION AND CONTROL STRATEGIES}

The precise delineation of the focuses in the endemicity area and the mapping of phytogeographical zones are necessary but not 


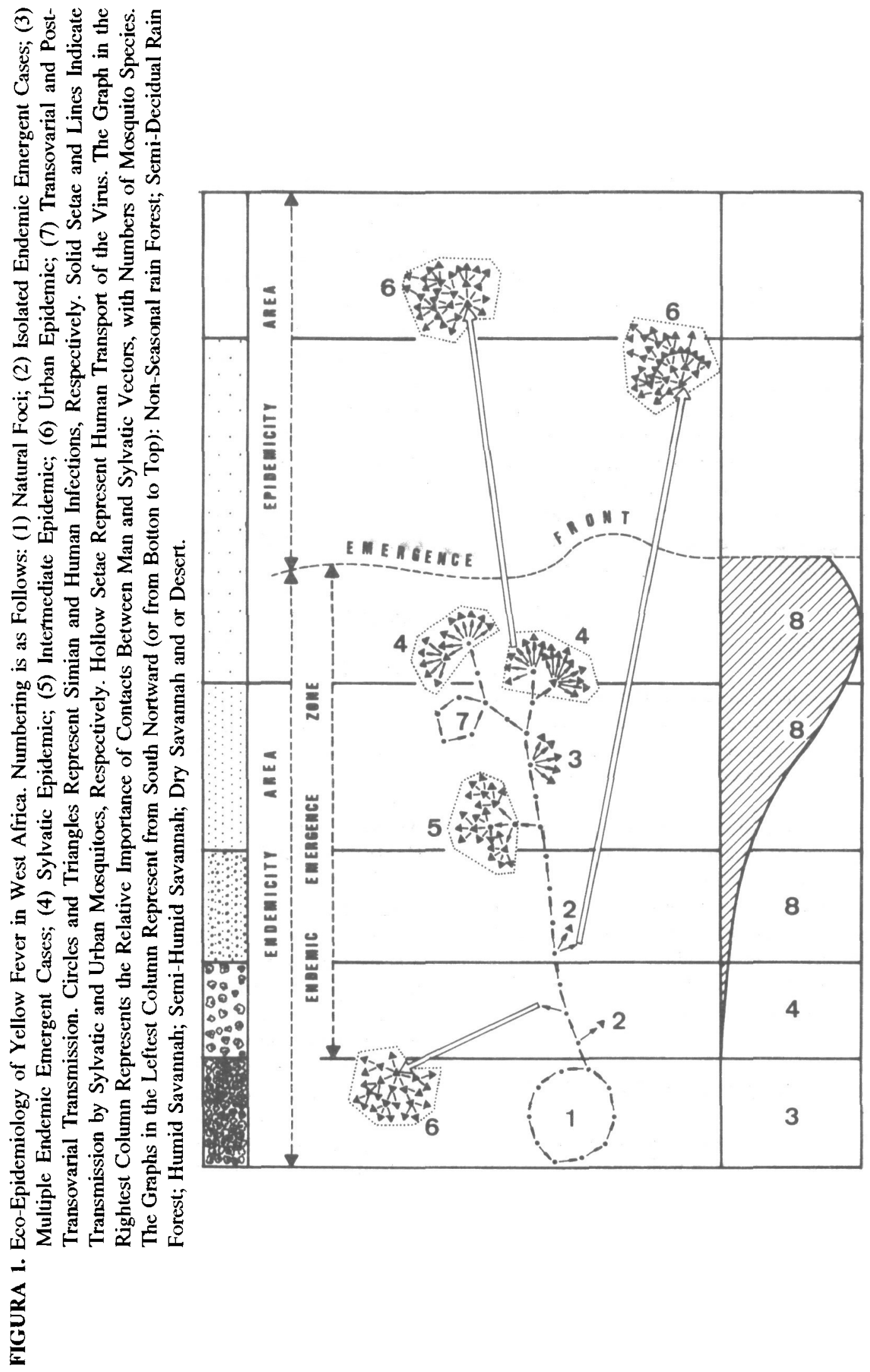


sufficient for establishing a prevention scheme of epidemics. The dynamics, including the viral displacements from South northward, may be modified by human changes on the environment, increasing the number of contacts with the mosquitoes' populations.

\section{PREVENTION ACCORDING TO THE RESULTS OF ECO-EPIDEMIOLOGICAL RESEARCHS}

Three measures are recommended: (1) establishment of an entomological monitoring system, inside the higher risk areas; (2) delimitation of the regions where vaccination must be perfect, based on ecological criteria (not on political ones) and (3) sanitary education in the rural and urban zones at risk of proliferation of $A$. aegypti and epidemics.

\section{CONTROL}

The control strategy will depend upon the type of epidemic: urban, intermediate (endemic emergences followed by interhuman transmission) and sylvatic (involving mainly A. furcifer).

Three type of decisions must be taken: (1) to do or not an anti-vectorial control simultaneously with a vaccination campaign; (2) when vector control is decided, to choose the most appropriate control measure against the vector species and (3) to establish a vaccination shedule in order to control the focus and its extention.

\section{COMMENTS AND CONCLUSIONS}

The topics presented previously may be discussed in relation with what is known of YF eco-epidemiology in Brazil (Hervé \& Travassos da Rosa, 1983; Travassos da Rosa et al., 1984; Pinheiro et al., 1986; Dégallier et al., 1991). Unfortunately, ecological studies have been much less developped in this country than in Africa, thus it is only possible to outline the major needs of studies: (1) the definition and delineation of the natural focuses of sylvatic transmission; (2) the importance of human-made environmental changes on the incidence of man-vectors contacts, and (3) the bioecological study of other potential vectors like Haemagogus albomaculatus, Sabethes spp. and others, the importance of which may also be undirectly modified by man.

The protection of human people from YF and other anthropo-zoonoses results from researches according to two principal axis: (1) the detailed study of the events and parameters which are determinant in the human intervention into the disease cycle; (2) the ecological appraisal of environmental changes due to man.

\section{ACKNOWLEDGMENTS}

The authors are very much indebted to ORSTOM (Paris) and FIOCRUZ (Rio de Janeiro) for funding of their travels to Rio de Janeiro, Brazil.

\section{RESUMO}

CORDELLIER, R. \& DEGALLIER, N. Ambiente, Transmissão de Arbovírus e Controle de Epidemias. Cad. Saúde Públ., Rio de Janeiro, 8 (3): 249-253, jul/set, 1992.

Para ilustrar as relações existentes entre os biótopos (ou zonas fitogeográficas), os vetores e hospedeiros vertebrados (incluindo o homem) de arbovírus e a epidemiologia, o conhecimento atual sobre a transmissão do vírus de febre amarela na África Ocidental é apresentado e discutido. Um modelo dinâmico foi desenvolvido para integrar a distribuição geográfica dos casos observados e o momento de sua ocorrência. Duas áreas principais, endemicidade e epidemicidade, foram definidas de acordo com a presença ou ausência de transmissão silvática macacomosquito.

A intensidade e o potencial dos contatos entre homem e vetores depende do grau das alteraçōes ambientais produzidas pelas atividades humanas, geralmente aumentando a 
extensão das áreas de ecótono onde os mosquitos estão ativos ao nível do solo. A prevenção e/ou controle de arboviroses requer estudos eco-epidemiológicos detalhados para que se conheça (1) o papel de cada vetor potencial em cada região fitogeográfica; (2) os fatores de risco para as pessoas vivendo nas proximidades ou nas áreas de transmissão silvestre; (3) quais são as prioridades (vacinação e/ou controle) para prevenir a expansão dos focos naturais.

Palavras-Chave: Febre Amarela; Vetores; Hospedeiros Vertebrados; Epidemiologia; Controle

\section{REFERENCES}

CORDELLIER, R., 1991. L'épidémiologie de la fièvre jaune en Afrique de l'Ouest. Bulletin de L'Organization Mondiale de la Santé, 69: 73-84. DEGALLIER, N.; TRAVASSOS DA ROSA, A. P. A.; VASCONCELOS, P. F. C.; GUERREIRO, S. C.; TRAVASSOS DA ROSA, J. F. S. \& HERVÉ, J. P., 1991. Estimation du taux de survie, de la densité relative et du taux d'infection d'une population d'Haemagogus janthinomys Dyar (Diptera, Culicidae) ayant fourni des souches de fièvre jaune en Amazonie brésilienne. Bulletin de la Societé de Pathologie Exotique, 84: 386-397.

GERMAIN, M., 1986. La fièvre jaune en Afrique de l'ouest: une dynamique spatiale. Orstom Actualités, juin-août: I-IV.
GERMAIN, M.; CORNET, M.; MOUCHET, J.; MONATH, T. P.; HERVE, J. P.; SALAUM, J. J.; CORDELLIER, R.; SALUZZO, J. F.; CAMICAS, J. L.; HERVY, J. P.; ROBERT, V.; DEUBEL, V.; GONZALEZ, J. P.; DIGOUTTE, J. P. \& DARWISH, D. O., 1982. Recent advances in research regarding sylvatic yellow fever in west and central Africa. Bulletin de L'Institut Pasteur, 80: 315-330.

HERVÉ, J. P. \& TRA VASSOS DA ROSA, A. P. A., 1983. Ecologia da Febre amarela no Brasil. Revista da Fundação SESP, 28: 11-19.

HERVE, J. P.; DÉGALLIER, N.; TRAVASSOS DA ROSA, A. P. A.; PINHEIRO, F. P. \& SÁ FILHO, G. C., 1986. Arboviroses: aspectos ecológicos. In: Instituto Evandro Chagas; 50 anos de contribuição d̀s ciências biológicas e d medicina tropical, vol. 1., pp. 409-437, Belém: Ed. Fundação Serviços de Saúde Pública.

PINHEIRO, F. P.; TTRAVASSOS DA ROSA, A. P. A.; FREITAS, R. B.; TRAVASSOS DA ROSA, J. F. S. \& VASCONCELLOS, P. F. C., 1986. Arboviroses: Aspectos clínico-epidemiológicos. In: Instituto Evandro Chagas; 50 anos de contribuição ds ciências biológicas e à medicina tropical, vol. 1., pp. 375-408, Belém: Ed. Fundação Serviços de Saúde Pública.

TRAVASSOS DA ROSA, A. P. A.; VASCONCELOS, P. C.; HERVE, J. P. \& TRAVASSOS DA ROSA, J. F. S., 1984. Febre amarela silvestre no Estado do Pará - Brasil, 1984. Boletim Epidemiológico, 15-16: 97-104. 